\title{
Wh-intensification at the Morphology-pragmatics Interface: An Indirect Look at Turkish through Translations into Polish
}

\section{Biçimbilim-edimbilim Arayüzünde $\boldsymbol{W h}$ 'nin Yoğunlaştırılması: Lehçe Çeviriler Üzerinden Türkçeye Dolaylı bir Bakış}

\author{
Annette HERKENRATH ${ }^{1}$
}

${ }^{1}$ Sorumlu yazar/Corresponding author: Annette Herkenrath (Assist. Prof.,), Uniwersytet im. Adama Mickiewicza w Poznaniu, Poznań, Wielkopolska, Poland

E-posta: annher3@amu.edu.pl ORCID: 0000-0002-2679-6495

Başvuru/Submitted: 20.10 .2021

Revizyon Talebi/Revision Requested:

10.11.2021

Son Revizyon/Last Revision Received:

15.11.2021

Kabul/Accepted: 25.11 .2021

Atıf/Citation: Herkenrath, Annette. "Whintensification at the Morphology-pragmatics Interface: An Indirect Look at Turkish through Translations into Polish." Türkiyat Mecmuas/Journal of Turkology 31, Özel Sayı (2021): 87-114 https://doi.org/10.26650/iuturkiyat.1018237

\section{ABSTRACT}

Based on a parallel corpus of contemporary novel beginnings, this study looks at two illocutionarily intensified wh-expressions, of syntactic interest in Turkish while morphological in Polish - discourse-pragmatic in both: wh... ki and wh-ż. With an eye on morpho-pragmatic interface discussions, the study explores how morphological marking in Polish helps to identify contexts in the Turkish original that a translator-as-reader interprets as illocutionarily intensified. In a first take, it is quantitatively established that the overlap between the two markers is smaller than expected: most $w h$-ż-constructions are translations of bare $w h$ in Turkish and at the same time, most wh... ki-constructions in the Turkish originals are translated into Polish as bare wh. Still, a closer look at context reveals that a certain quality of illocutionary intensification is given to all the findings; in many cases, intensification also brings about a dismissal of the question. Structurally, the approach has helped with a closer look at alternative strategies of $w h$-intensification in both languages, including $w h$ fronting and modifiers as well as lexical means and contextual cues. Since the alternative strategies, in particular wh-movement in Turkish, have often been a topic of complex discussions, the parallel-corpus method proves helpful in identifying constructions deserving of a closer look. .

Anahtar kelimeler: Wh, illocution, morphology, Turkish, Polish, Parallel corpus

\section{öz}

Çağdaş roman başlangıçlarından ibaret paralel bir derleme dayanan bu çalışma, Türkçede sözdizimsel ilgiye sahip, Lehçede morfolojik - her ikisinde de söylemsel-pragmatik olan, edimsözsel olarak yoğunlaştırılmış iki wh-ifadesine bakıyor: wh... ki ve wh-ż. Morfo-pragmatik arayüz tartışmalarını göz önünde bulunduran bu çalışma, Lehçedeki morfolojik işaretlemenin, bir okuyucuolarak-çevirmenin edimsel olarak yoğunlaştırılmış olarak yorumladığı Türkçe orijinaldeki bağlamları belirlemeye nasıl yardımcı olduğunu araştırıyor. Illk bir yaklaşımda, iki işaretleyici arasındaki örtüşmenin beklenenden daha küçük olduğu nicel olarak tespit edilmiştir: $w h$-ż-yapılarının çoğu Türkçedeki yalın wh'nin çevirisidir ve aynı zamanda Türkçedeki wh... ki yapılarının çoğu Lehçeye yalın wh olarak çevrilir. Yine de, bağlama daha yakından bakıldığında, tüm bulgularda belirli bir edimsözsel yoğunlaştırma niteliğinin verildiği ortaya 
çıkıyor; pek çok durumda, yoğunlaşma sorunun reddedilmesini de beraberinde getirir. Yapısal olarak, yaklaşım, wh-nin cümlenin önüne hareketi, değiştiriciler ve ayrıca sözcüksel araçlar ve bağlamsal ipuçları dahil olmak üzere her iki dilde de wh-yoğunlaştırmanın alternatif stratejilerine daha yakından bakmamıza yardımcı oldu. Alternatif stratejiler, özellikle de Türkçe'de wh-hareketi, genellikle karmaşık tartışmaların konusu olduğundan, paralel derlem yöntemi, daha yakından bakmayı hak eden yapıların belirlenmesinde yardımcı olur..

Keywords: Wh, edimsöz, Biçimbilim, Türkçe, Lehçe, Paralel derlem 


\section{Introduction}

Wh-expressions - e.g., kim, nasll, ne, neden in Turkish, kto, jak, co, dlaczego in Polish, 'who, how, what, why' in English - while they contain an element that verbalises a 'specific knowledge deficit', are not per se interrogative words. By this I mean that they do not necessarily address the knowledge deficit to a hearer who then feels obliged to fill it, as has been suggested. ${ }^{1}$ They do have this illocutionary potential and can be used to form 'content questions' or 'constituent interrogatives'; however, depending on context, their full interrogative potential can be activated, deactivated, semi-activated, diverted, or syntactified. ${ }^{2}$ It can also be intensified.

In Turkish, the illocutionary quality of $w h$ is not specified at the morphological level but rather in terms of - visible or invisible, full or partial - syntactic movement, clause embeddedness status, discourse-pragmatic circumstances, or sometimes illocution markers in the form of particles such as $k i$, as in example (1a):

(1a) Turkish

$\begin{array}{lllll}\text { Kim } & \text { ilgilen-ir } & \boldsymbol{k i} \text { bizim } & \text { hikâye-miz-le } & \text { bir } \\ \text { who be.interested-AOR } & k i \text { POSS1PL } & \text { story-POSS1PL-INS } & \text { one } \\ \text { avuç dinozor-dan } & \text { başka!' } & & \\ \text { handful dinosaur-ABL } & \text { other } & & \\ \text { 'Who the heck is interested in our story other than a handful of dinosaurs!' }\end{array}$

On the other hand, wh-expressions in Turkish do have morphological slots, mainly for case and sometimes number. Then what about morphological slots for illocutionary intensification? This seems to be an option in Polish; see (1b):

Polish

$\begin{array}{lccc}\text { Kogó- } \dot{z}, & \text { oprócz } & \text { garstki star-ych } & \text { dinozaurów, } \\ \text { who.ACC- } \dot{z} & \text { apart.from } & \text { handful old-GEN.PL } & \text { dinosaur-GEN.PL } \\ \text { interesuj- } a & \text { moje } & \text { opowieści. } & \\ \text { interest.PRS-3PL } & \text { POSS1SG } & \text { story.PL } & \end{array}$

'Whom the heck, apart from a handful of old dinosaurs, do my stories interest!'

1 Konrad Ehlich \& Jochen Rehbein, "Sprachliche Handlungsmuster", in Interpretative Verfahren in den Sozial- und Textwissenschaften (Stuttgart: Metzler, 1979), 243-274; Jochen Rehbein, "Remarks on the empirical analysis of action and speech", Journal of Pragmatics 8 (1984), 49-63; Jochen Rehbein, "Zum Modus von Äußerungen”, in Grammatik und mentale Prozesse (Tübingen: Stauffenburg, 1999), 91-142; Angelika Redder, "Sprachwissen als handlungspraktisches Bewusstsein: Eine funktional-pragmatische Diskussion”, Didaktik Deutsch 5 (1998), 60-76.

2 Annette Herkenrath, Wh-Konstruktionen im Türkischen (Wiesbaden: Harrassowitz, 2011), 111-234, 359-390.

3 Oya Baydar, Kayıp söz (İstanbul: Can Yayınları, 2011 [2007]), 38.

4 Oya Baydar, Utracone Stowo, translated by Anna Akbike Sulimowicz (Katowice: Wydawnictwo Sonia Draga, 2013), 42. 
This paper, obviously, is not about Polish; it is, however, focused on one small area where Turkish and Polish meet in translation. If Polish has special illocutionary markers suffixed to $w h$, then their appearance in translations of Turkish texts might shed some indirect light on illocutionary issues of $w h$-constructions in Turkish that have so far been hard to grasp and have mainly been discussed in terms of syntactic movement. ${ }^{5}$

Given this typological situation, which involves the necessity to view together morphological issues on the one hand and discourse-pragmatic phenomena of illocution on the other, this study sets out to explore the 'morphology-pragmatics interface' of $w h$, looking at patterns of correspondence in the Turkish original and Polish translation of a small handful of contemporary novel beginnings. It is organised as follows: Section 2 briefly reviews morpho-pragmatic interface discussions, part-of-speech categorisations, illocutionary modifications and morphological slots of $w h$. Section 3 describes the empirical groundwork. Sections 4 to 6 present the data analysis: 4 looks at a small area of correspondence between two means of wh-intensification in the two versions. 5 takes as a starting point some marked wh-elements in the Polish translations for an exploration into their original Turkish contexts. 6 does the opposite in starting from wh-constructions marked in the Turkish original for an exploration of what represents them in the translations. 7 synthesises the findings in terms of formal correspondences as well as emotional-illocutionary meanings.

\section{Theoretical framework}

This chapter briefly reviews some issues related to the morphology-pragmatics interface as an internally diverse field of study with $w h$ as a research gap, part-of-speech categorisations of $w h$, ways of diverting or intensifying the hearer-directed interrogative potential of $w h$, and morphological slots of $w h$.

\subsection{The 'morphology-pragmatics interface' as a field of study}

Next to better-known interface disciplines such as 'morphosyntax' or the 'syntaxpragmatics interface', recent years have seen the emergence of a research direction referred

5 Jaklin Kornfilt, "On Some Infinitival Wh-Constructions in Turkish”, Dilbilim Araştırmaları 1996, 192-215; Jaklin Kornfilt, Turkish (London: Routledge, 1997), 27-31; Jaklin Kornfilt, "On rightward movement in Turkish", in The Mainz Meeting: Proceedings of the Seventh International Conference on Turkish Linguistics, August 3-6, 1994 (Wiesbaden: Harrassowitz, 1998), 107-123; A. Sumru Özsoy, “A'-dependencies in Turkish”, in Current Issues in Turkish Linguistics (Ankara: Hitit Yayınları, 1996), 140-158; A. Sumru Özsoy, "Turkish as a (non)-whmovement language", in Turcological Letters to Bernt Brendemoen (Oslo: Novus Press, 2009), 221-232; Marcel Erdal, "Das Nachfeld im Türkischen und im Deutschen, in Türkisch und Deutsch im Vergleich (Wiesbaden: Harrassowitz, 1999), 53-94; Didar Akar, "Wh-questions in Turkish", in Current Issues in Turkish Linguistics, Volume II. Ankara: Hitit Yayınları, 2000, 67-74; Aslı Göksel \& A. Sumru Özsoy, "Is there a focus position in Turkish?", in Studies on Turkish and Turkic Languages (Wiesbaden: Harrassowitz, 2000), 219-228; Asl1 Göksel \& A. Sumru Özsoy, “dA: as a focus/topic associated clitic in Turkish”, Lingua 113 (2003), 1143-1167; Selçuk İşsever, "A syntactic account of wh-in-situ in Turkish”, in Essays on Turkish Linguistic: Proceedings of the 14th International Conference on Turkish Linguistics, August 6-8, 2008 (Wiesbaden: Harrassowitz, 2009), 103-112; Herkenrath, Wh-Konstruktionen im Türkischen, 54-63, 328-337. 
to as 'morphopragmatics' or the 'morphology-pragmatics interface'. This field has been studied under various perspectives by a number of authors, roughly since the 1980 s. Zwicky \& Pullum speak of 'non-context-free grammar', coining the term 'expressive morphology' for a group of morphological phenomena that realise pragmatic functions of playfulness; their focus is on deprecative reduplications, certain derivational processes, and infixation of expletives. ${ }^{6}$ Kiefer's 'extragrammatical' focus is on pragmatic effects of grammatical morphology, among them evidentials in Turkish and evaluative connotations of certain plural endings in Polish. ${ }^{7}$ Some more recent areas of interest in this field have been links between morphophonological variation and hearer group anticipation in commercial advertising in Swahili, ${ }^{8}$ between verb derivation and 'socio-expressive' attitudes in Greek, ${ }^{9}$ and the pragmatics of diminutives, augmentatives, honorifics, and other morphological stance markers in Italian and a few other languages. ${ }^{10} \mathrm{Wh}$, which additionally brings in a syntactic component, has, to my knowledge, not yet been on the morphopragmatic agenda.

\section{2. $W h$ as a cross-part-of-speech category}

The category wh is a generativist concept dating back to early discussions of syntactic movement. It has since come to be widely used in linguistic typology, where its cross-categorial status is recognised. ${ }^{11}$ In descriptive grammars of Turkish and Polish, wh-expressions tend to be listed under a diversity of part-of-speech categories, including interrogative, relative and indefinite pronouns, and interrogative adverbs as well as parts of nominal constituents, such as determiners, quantifiers, and conjunctions. Oftentimes, there is not any explicit mention of a double status. These discussions are relevant for the following reason: if, depending on its part-of-speech status, $w h$ can be more or less deeply embedded in the sentence structure, e.g. inside an NP, and can still carry an illocutionary marker, then this increases the distance between illocution and the verb, which has been seen as the standard carrier of finiteness and also of illocution (motivating various syntactic operations); in other words CP phenomena might reach further below than just the IP area.

6 Arnold Zwicky \& Geoffrey Pullum, "Plain morphology and expressive morphology", Proceedings of the Thirteenth Annual Meeting of the Berkeley Linguistics Society 1987: 330-340. Retrieved July 30, 2021. DOI: 10.3765/bls.v13i0.1817.

7 Ferenc Kiefer, "Morphology and Pragmatics", in Handbook of Morphology (Oxford: Blackwell, 1998), $272-280$.

8 Amani Lusekelo, "Morphology-Pragmatics Interface: The Case of the Tanzanian Commercials in Swahili Newspapers", Afrikanistik online 2010: 1-22, retrieved 30 July 2021. http://www.afrikanistik-online.de/ $\operatorname{archiv/2010/2711.~}$

9 Chariton Charitonidis, "The Morphology-Pragmatics Interface in Modern Greek Compounding”, Poznań Studies in Contemporary Linguistics 51/1 (2015), 27-73.

10 Lavinia Merlini Barbaresi \& Wolfgang U. Dressler, "Pragmatic explanations in morphology", Word Knowledge and Word Usage: A Cross-Disciplinary Guide to the Mental Lexicon (Berlin: De Gruyter Mouton, 2020), 405-454.

11 Viveka Velupillai, An Introduction to Linguistic Typology (Amsterdam: Benjamins, 2012), 356-359. 
Grammars of Turkish mention wh-expressions as interrogative pronouns, adjectives, and adverbs (soru zamirleri, soru sifatlart, soru zarflart), ${ }^{12}$ as various parts of nominal constituents (i.e., numerals, deictics, possessors, modifiers, or heads), ${ }^{13}$ as definite and indefinite interrogative determiners, pronouns, locative pronouns, modifiers and quantifiers, ${ }^{14}$ and also as components of some indefinite or hypothetical expressions, i.e., belirsizlik sıfatları such as birkaç 'some, a few', kimi 'some', and kimse 'somebody, nobody, anyone'. ${ }^{15}$ In Turkish, wh-expressions do not function as subordinating conjunctions ${ }^{16}$ nor as relativisers.

Grammars of Polish mention wh-expressions as interrogative, relative and indefinite pronouns, as adjectives and adverbs, and as subordinating conjunctions. While both the relativising and the subordinating employments markedly distinguish Polish from Turkish $w h$, there has, to my knowledge, not yet been any direct comparison in this respect. The category 'pronoun' includes interrogative and relativising $w h$, sometimes also indefinites and negatives. ${ }^{17} \mathrm{Wh}$-expressions functioning as adverbs or adjectives are subclassified as comparatives, negatives (nigdzie 'nowhere'), interrogatives, temporals, ${ }^{18}$ and 'pro-adverbs' ${ }^{19}$ Wh-expressions functioning as conjunctions are often mentioned. ${ }^{20}$ Sadowska differentiates between lower and higher syntactic levels at which a junction occurs, with jak 'as, like; if; when' also occurring between (non-clausal) phrases. ${ }^{21}$

12 Geoffrey L. Lewis, Turkish Grammar (Oxford: Oxford University Press, 1997, 72-74; Tahsin Banguoğlu, Türkçenin Grameri (İstanbul: Edebiyat Fakültesi Basımevi, 1974), 367f, 383; Zeynep Korkmaz, Türkiye Türkçesi grameri: Şekil bilgisi (Ankara: Türk Dil Kurumu, 2009 [2003]), 441-449, 393-395, 523.

13 Kornfilt, Turkish, $16 \mathrm{f}$.

14 Aslı Göksel \& Celia Kerslake, Turkish: A Comprehensive Grammar (London: Routledge, 2005), 202f, 261, 280, 296-304.

15 Kornfilt, Turkish, 296, 432; Korkmaz, Türkiye Türkçesi grameri: Şekil bilgisi, 395-398; Göksel, Kerslake, Turkish: A Comprehensive Grammar, 147; Nigâr Oturakç1, "Question words as indefinite pronouns in Turkish", in The Szeged Conference: Proceedings of the 15th International Conference on Turkish Linguistics held on August 20-22, 2010 in Szeged (Szeged: University of Szeged, Department of Altaic Studies, 2012), 381-388.

16 Kornfilt, Turkish, 11f, 53; Herkenrath, Wh-Konstruktionen im Türkischen, 273-285, 338-340.

17 M. Sciborski, Abrégé De La grammaire polonaise: Sélon les principes \& le raisonnement de la Grammair nationale suivi des Dialogues \& d'un petit Vocabulaire Alphabétique (Lucko: Imprimerie privilégiée des Dominicains, 1798), 42; Napoléon Orda, Grammaire analytique et pratique de la langue polonaise à l'usage des français (Paris: Martinet, 1856), 82-84, 90; Erazm Rykaczewski, Grammaire de la langue polonaise: Contenant des règles appuyées sur les examples tirés des meilleurs auteurs polonais destinée principalement à l'usage des écoles polonaises à Paris (Berlin et Posen: Librairie B. Behr, 1861), 60-65; Dana Bielec, Polish: An Essential Grammar (London: Routledge, 1998), 152-156; Oscar E. Swan, A grammar of contemporary Polish (Bloomington: Slavica, 2002), 159-163, 181; Iwona Sadowska, Polish: A Comprehensive Grammar (London: Routledge, 2011), 299-305.

18 Orda, Grammaire analytique et pratique de la langue polonaise à l'usage des français, 87, 90, $231-233$.

19 Swan, A grammar of contemporary Polish, 179-181.

20 Sciborski, Abrégé De La grammaire polonaise: Sélon les principes \& le raisonnement de la Grammair nationale suivi des Dialogues \& d'un petit Vocabulaire Alphabétique, 83-84; Rykaczewski, Grammaire de la langue polonaise: Contenant des règles appuyées sur les examples tirés des meilleurs auteurs polonais destinée principalement à l'usage des écoles polonaises à Paris, 141-147; Bielec, Polish: An Essential Grammar, 229-239); Swan, A grammar of contemporary Polish,.

21 Sadowska, Polish: A Comprehensive Grammar, 582-602. 


\subsection{Diverting and intensifying $w h$}

As seen above, sentence-level-connective, i.e., conjunction-like and relativising, employments of $w h$, are a feature of Polish but not of Turkish. Such uses are one way in which the interrogative potential of $w h$ can be diverted; others are morphological. In this connection, grammars of Polish mention a number of morphological procedures that can transform the meaning of a $w h$-expression into that of an indefinite pronoun, deriving in particular $w h$-forms ending in $-\dot{s}$ (e.g.,jakis' 'a certain'), -kolwiek (e.g., którykolwiek 'whoever'), or prefixed by a negative (e.g., niektóry 'somebody'), which may serve to express a given object 'd'une façon indéterminée et générale'. ${ }^{22}$ Orda in this connection speaks of 'vagueness or uncertainty markers', adding forms such as kiedyśindziej 'sometime else', kiedybąz' 'whenever', niekiedy or kiedy niekiedy 'from time to time', niegdyś 'once, some time ago', gdzieniegdzie 'here and there', and niektóry 'somebody'. ${ }^{23}$ Other authors also speak of 'vagueness modifiers', Swan providing quite a large overview of $w h$-based indefinite forms ${ }^{24}$ More recently, Sadowska classifies her 'interrogative, indefinite, and negative pronouns' in a unified paradigm, e.g. kto, ktoś, ktokolwiek, nikogo 'who, somebody, anybody, nobody'; she also approaches suffix ordering in mentioning that case marking occurs closer to the stem than indefiniteness marking. ${ }^{25}$

In Turkish, $w h$ or the closest verb can host a conditional copula clitic, or $w h$ can be preceded by a determiner or quantifier, bringing about effects of indefiniteness or hypotheticality rather than interrogativity (kimse or kim ... $-s A$ 'whoever', birkaç 'a few', herhangi 'any kind of', etc.). ${ }^{26}$ Herkenrath discusses similar phenomena of $w h$-diversion in conversational contexts in which the potential of a hearer-directed quest for an answer is delegated to a context remote from the speech situation. ${ }^{27}$

By way of intensification, illocutionary qualities such as focus or information status have been discussed in analyses of syntactic movement in Turkish and other languages, mainly as part of the CP project of generativist universal grammar, which links syntax to discourselevel categories while assuming an underlying universality of functional categories that is independent of their actual realisation in a given language. ${ }^{28}$ The bulk of such work has been

22 Sciborski, Abrégé De La grammaire polonaise: Sélon les principes \& le raisonnement de la Grammair nationale suivi des Dialogues \& d'un petit Vocabulaire Alphabétique, 43-45.

23 Orda, Grammaire analytique et pratique de la langue polonaise à l'usage des français, 88, 232-234, 242.

24 Rykaczewski, Grammaire de la langue polonaise: Contenant des règles appuyées sur les examples tirés des meilleurs auteurs polonais destinée principalement à l'usage des écoles polonaises à Paris, 65-66; Bielec, Polish: An Essential Grammar, 152-156); Swan, A grammar of contemporary Polish, 185-186.

25 Sadowska, Polish: A Comprehensive Grammar, 299-302.

26 Oturakçı, "Question words as indefinite pronouns in Turkish", 381-388.

27 Herkenrath, Wh-Konstruktionen im Türkischen, 268-273, 394, 306-308.

28 Noam Chomsky, Knowledge of Language: Its Nature, Origin and Use (N.Y.: Praeger, 1986), 160-161; Luigi Rizzi, “The Fine Structure of the Left Periphery”, in Elements of Grammar (Dordrecht: Kluwer, 1997), 281-337; Guglielmo Cinque \& Luigi Rizzi, "The Cartography of Syntactic Structures", in The Oxford Handbook of Linguistic Analysis (Oxford: OUP, 2010), 51-66. 
based on introspectively constructed data. By contrast, Erdal, more specifically Turcological, investigates illocutionary motivations of verb fronting in Turkish in a set of natural data, literary as well as some oral, which he interprets in terms of their illocutionary quality. ${ }^{29}$ Erdal connects verb fronting, which he observes in interrogative, imperative, and assertive constructions, to illocutionary phenomena of emotionality, such as a repeated threat, anger, desperation, impulsive dynamism, or suddenness. These observations can be classified as phenomena of intensification; however, they do not yet relate to $w h$ in particular.

Göksel \& Kerslake mention a number of discourse markers (hani, acaba, yoksa, and bakalım, referred to as 'modal adverbs' or 'interjections'), which in interrogative contexts (both q and wh) may express mental categories such as shared presumptions, doubt, curiosity, a sudden change of mind, anticipation, and disbelief; such nuances can either reduce or intensify the interrogative character of an utterance. ${ }^{30}$ Specifically in connection with Turkish $k i$, several authors discuss emotional or illocutionary meanings of its non-subordinating, particle-like uses. Lewis discusses the often very close link of $k i$ to the verb (despite its ability to introduce a clause in other constructions); he speaks of a 'vestigial $k i$ ', derived from a consequential conjunctional use. ${ }^{31}$ Some such uses, in (q-)interrogative contexts, may express anxiety as an emotion. Erguvanl Taylan (1981) identifies an emphatic use, which she considers distinct from any Persian emphatic uses and also from subordinating $k i$, for which she assumes an ellipsis. ${ }^{32}$ Göksel \& Kerslake treat sentence-final $k i$ as an 'adversative connective' with a 'repudiative' function, occurring mainly in questions (next to negatives). ${ }^{33}$ They derive this function in terms of an elided subordinate clause with an optative verb and a purpose meaning, somewhat similarly to Erguvanlı Taylan.

Intensifying expressions in Polish wh seem to be more morphological. Sciborski mentions some $w h$-forms ending in $-\dot{z}$ (cóż 'what- $\dot{z}$ ', in his French translation: 'quoi donc') or followed by a 'particle' $\dot{z} e$, in some phonological environments. ${ }^{34}$ Vater hints at some adverbial meaning of $-\dot{z} .{ }^{35}$ Orda mentions an intensified form of the q-element $c z y$, namely $c z y \dot{z} .{ }^{36}$ Next to a number of $w h$-based expressions ending in - $\dot{z}$, he also lists several conjunctions such as takize, te $\dot{z}$ 'also', $g d y \dot{z}$ 'because', alboz 'or (is it that)', jakoz 'indeed', and coz 'well', not all wh-based and not all semantically predictable. According to Orda, the function of $-\dot{z}$ (next to that of some other

29 Erdal, "Das Nachfeld im Türkischen und im Deutschen, 66-71.

30 Göksel, Kerslake, Turkish: A Comprehensive Grammar, 307-309.

31 Lewis, Turkish Grammar, 213f, 265.

32 Eser Erguvanlı Taylan, "A case of syntactic change: $k i$ constructions in Turkish”, Bogaziçi Üniversitesi Dergisi (Istanbul) 8-9 (1981), 111-139.

33 Göksel, Kerslake, Turkish: A Comprehensive Grammar, 522-523.

34 Sciborski, Abrégé De La grammaire polonaise: Sélon les principes \& le raisonnement de la Grammair nationale suivi des Dialogues \& d'un petit Vocabulaire Alphabétique, 42-43.

35 Johann-Sévérin Vater, Grammaire abrégée de la langue polonaise consistant en tableaux, règles et examples (Halle: Gebauer/ Strasbourg: Levrault, 1807), 17.

36 Orda, Grammaire analytique et pratique de la langue polonaise à l'usage des français, 231, 234-235, 256-259. 
forms that are not part of my data) is to express a question or an uncertainty. ${ }^{37}$ Rykaczewski classifies $-\dot{z}$ as one of several intensifiers, mainly of interrogativity. ${ }^{38}$ Swan classifies $-\dot{z} /-\dot{z} e$ as a particle that 'may be added to certain interrogative or other expressive words for emphasis or in order to express surprise'; in his translations into English, he adds 'but' as well as an intensifying punctuation, e.g. kiedyz 'but when?!', non-wh interrogative czyż 'really?!'; noninterrogatives include ależ or proszę̇ 'come now!'. ${ }^{39}$ Sadowska characterises forms such as jakiż 'what', któż 'who', cóż 'what', and czemuż 'why' as 'bookish', 'literary', and 'stylistically charged', not referring to any intensifying or emphatic illocutionary function. ${ }^{40}$

\subsection{Morphological slots of $\boldsymbol{w h}$}

One can now compare the morphological possibilities of $w h$ in the two languages. These seem to often be in complementary distribution, such that the only category they do have in common seems to be case. Beyond that, Turkish wh can be preceded by a determiner or quantifier whereas, according to what has been seen, its Polish counterpart cannot. Polish wh can carry a negative prefix, Turkish $w h$ cannot. Turkish $w h$ can host a conditional copula or a derivational, specifically nominalising, suffix, Polish $w h$ cannot. Turkish $w h$ can be pluralised and possessed, Polish wh cannot. In terms of illocutionary qualification, Polish wh can host morphological or enclitic markers of indefiniteness and emphasis, where for Turkish there exists a possibility of a morphologically unbound illocutionary particle or discourse marker, $k i$. Table 1 schematically overviews these options:

37 Orda, Grammaire analytique et pratique de la langue polonaise à l'usage des français, 242.

38 Rykaczewski, Grammaire de la langue polonaise: Contenant des règles appuyées sur les examples tirés des meilleurs auteurs polonais destinée principalement à l'usage des écoles polonaises à Paris, 65-66.

39 Swan, A grammar of contemporary Polish, 187.

40 Sadowska, Polish: A Comprehensive Grammar, 302. 
Table 1: Morphological slots for $w h$-expressions in Turkish and Polish

\begin{tabular}{|c|c|c|c|c|c|c|c|c|c|}
\hline & $\begin{array}{l}\text { DET-/ } \\
\text { QTF- }\end{array}$ & NEG- & $w h$ & $\begin{array}{l}\text {-COP.CD/ } \\
\text {-DER }\end{array}$ & $-P L$ & -POSS & -CASE & $\begin{array}{l}\text {-INDEF/ } \\
\text {-EMPH }\end{array}$ & [...] PTC \\
\hline \multirow{7}{*}{ Turkish } & + & - & + & + & + & + & + & - & + \\
\hline & & & kim & $-s e$ & -ler & $-i m i z$ & $-e$ & & \\
\hline & & & kim & $-l i k$ & & & & & \\
\hline & & & nere & & & $-s i$ & & & \\
\hline & bir- & & $k a c ̧$ & & & & & & \\
\hline & her- & & hangi & & & & & & \\
\hline & & & nerede & & & & & & $k i$ \\
\hline \multirow{9}{*}{ Polish } & - & + & + & - & - & - & + & + & - \\
\hline & & nie- & który & & & & & & \\
\hline & & nie- & $g d y$ & & & & & $-s^{\prime}$ & \\
\hline & & & ktory & & & & & -kolwiek & \\
\hline & & & $k$ & & & & $-\operatorname{ogo}$ & -kolwiek & \\
\hline & & & $c z$ & & & & $-y m$ & $-s^{\prime}$ & \\
\hline & & & gdzie & & & & & $-\dot{z}$ & \\
\hline & & & $c z$ & & & & -ети & $-\dot{z}$ & \\
\hline & & & $c z$ & & & & $-y m$ & $-\dot{z} e$ & \\
\hline
\end{tabular}

The present study looks at the intensification of the interrogative quality that is inherent as a potential in $w h$. As has been seen, this can be expected to be realised morphologically in Polish but syntactically in Turkish.

\section{Distributional pattern in a parallel corpus}

The present study follows the basic assumption that illocutionary quality can be crosslinguistically compared and attempts to undertake such a comparison on the basis of two sets of literary data: four beginnings of contemporary novels in their Turkish originals ${ }^{41}$ together with their Polish translations. ${ }^{42}$ The novels were chosen to represent four different writers and four different translators. The texts were linearly tagged for any kinds of $w h$-expressions as part of a parallel reading process. Particular attention was paid to $w h$-constructions with $k i$ in Turkish and $w h$-elements ending in $-\dot{z}$ in Polish, yielding 30 findings, half of them in the

41 Baydar, Kayıp söz; Yaşar Kemal, Binboğalar Efsanesi (İstanbul: Yapı Kredi, 2007 [1971]); Perihan Mağden, Biz Kimden Kaçıyorduk Anne? (İstanbul: Can Yayınları, 2007); Orhan Pamuk, Benim Adım Kırmızı (İstanbul: İletişim Yayınları, 1998 [1990]).

42 Baydar, Utracone Słowo; Yaşar Kemal, Legenda Tysiąca Byków, translated by Wojciech Hensel (Warszawa: Państwowy Instytut Wydawniczy, 1983); Perihan Mağden, Przed Kim Uciekamy, Mamo?, translated by Marcin Błaszak (Warszawa: Șwiat Książki, 2011); Orhan Pamuk, Nazywam Się Czerwień, translated by Danuta Chmielowska (Kraków: Wydawnictwo Literackie, 2007). 
beginning of The Lost Word; see Table $2 .^{43}$ Together with further wh-occurrences that might be considered as candidates for a somehow intensified interrogative illocution, the 30 findings were entered into a spreadsheet concordance and were aligned between the two versions.

Table 2: Corpus overview ( $\Sigma: 30 w h$-findings under closer consideration)

\begin{tabular}{|l|c|c|c|c|}
\hline Turkish original passage & Polish translation passage & Translator & Title in English & Findings \\
\hline Baydar, Kayıp Söz, 9-54 & Baydar, Utracone Stowo, 7-63 & Sulimowicz & The Lost Word & 15 \\
\hline $\begin{array}{l}\text { Kemal, Binboğalar Efsanesi, } \\
\text { 9-53 }\end{array}$ & $\begin{array}{c}\text { Kemal, Legenda Tysiaca } \\
\text { Byków, 7-54 }\end{array}$ & Hensel & $\begin{array}{c}\text { The Legend of the } \\
\text { Thousand Bulls }\end{array}$ & 5 \\
\hline $\begin{array}{l}\text { Mağden, Biz Kimden } \\
\text { Kaçıyorduk Anne?, 13-33 }\end{array}$ & $\begin{array}{c}\text { Mağden, Przed Kim Uciekamy, } \\
\text { Mamo?, 11-36 }\end{array}$ & Błaszak & Whom Were We & 7 \\
\hline $\begin{array}{l}\text { Pamuk, Benim Adım Kırmızl, } \\
\text { 6-25 }\end{array}$ & $\begin{array}{c}\text { Pamuk, Nazywam Się } \\
\text { Czerwień, 7-62 }\end{array}$ & Chmielowska & My Name Is Red & 3 \\
\hline
\end{tabular}

The compilation reveals $17 w h . . . k i$-findings in the Turkish data and also $17 w h$-ż-findings in the Polish data. The overlap is small: only four of the $w h$-findings contain both $k i$ in the Turkish original and $-\dot{z}$ in the Polish translation; example (1) above is one such finding. In all the remaining cases, only one version contains an intensifier $(k i$ or $-\dot{z})$, while the other is unmarked. Thus, the bulk of Polish $w h$-ż-findings are translations of Turkish bare $w h$ or, more rarely, emerge as translations of non-wh-constructions. The bulk of Turkish wh...kiconstructions ends up as bare $w h$ in the Polish translations or can, rarely, be associated with negation; see Table 3:

Table 3: Distributional pattern of $w h-\dot{z}$ and $w h \ldots k i$

\begin{tabular}{|c|c|c|c|c|c|}
\hline & $w h \ldots k i$ & bare $w h$ & JNC & NEG & $\Sigma$ \\
\hline$w h-\dot{z}$ & 4 & 11 & 1 & 1 & 17 \\
\hline bare $w h$ & 11 & - & - & - & 11 \\
\hline NEG- $w h$ & 1 & - & - & - & 1 \\
\hline NEG & 1 & - & - & - & 1 \\
\hline$\Sigma$ & 17 & 11 & 1 & 1 & 30 \\
\hline
\end{tabular}

From this picture, the following four questions arise: (1) How come ki gets lost in the Polish translations? (2) How come $-\dot{z}$ emerges in the Polish translations when there is no $k i$ in the original? (3) How can the still existing overlap be accounted for? (4) How can the range of functional meanings expressed by these two forms be characterised?

In what follows, a closer look will be taken from three subsequent perspectives: first, the small area of overlap will be briefly discussed. Second, those constructions that have ended up

43 One might speculate as to the reasons for this unequal distribution. These can be assumed to be related to the expressive styles of individual writers and translators, the social-communicative and mental-internal scenes that they create, or any relevant features of the narrative content. I cannot go into this, but it might be an interesting topic to further pursue. I did indeed first come across the phenomenon under investigation during my parallel reading of the Turkish and the Polish version of Baydar's novel, later expanding my corpus on this basis; the phenomenon might otherwise have escaped my notice. 
as $w h-\dot{z}$ will be given a closer qualitative look; in a third step, those constructions that started as $w h . . . k i$ will be considered.

\section{The overlaps}

In example (1a) and (1b) above, both the author and the translator seem to have chosen to mark the $w h$, resulting in $w h \ldots k i$ and $w h-\dot{z}$, respectively. The passage contains the ruminations of a writer in a productive crisis who is coming to realise that his best times may be over. The question he is asking (Kim ilgilenir $k i$ 'Who the heck is interested') no longer requires an explicitly verbalised answer. The three remaining findings, not shown here for reasons of space, present similar pictures: more or less painfully existential questions are being asked in interior monologue ${ }^{44}$ or imagined dialogue $;{ }^{45}$ the answer in all of these cases, if given, would be negative: 'nothing' or 'nobody'.

When looking at the context of these findings, one may come to challenge the notion of 'intensified wh-illocution'. What actually happens is that a knowledge deficit is briefly presented, but since the answer would be clearly negative, the search is not seriously pursued. Put differently: the question is asked and simultaneously dismissed. Thus, while at the content level, the existential topic as such may be characterised by a certain level of emotional intensity, at the communicative level, the request for an explicitly verbalised answer is withdrawn. These examples come close to Göksel \& Kerslake's characterisation of some sentence-final ki uses as 'adversative' or 'repudiative'; they find this usage in questions but also in negatives. ${ }^{46}$ As a result of these observations, one might refer to this phenomenon not so much as 'intensified $w h$ ' but rather as 'dismissive $w h$ '.

\section{Looking from the $\dot{\boldsymbol{z}}$-side}

Among the thirteen $w h$-ż-occurrences in the Polish translations that are not based on $w h \ldots$ $k i$ in the Turkish original, one finds two in which the Turkish version does not contain $w h$ at all. In one instance, Polish $g d y \dot{z}$ 'because' has been used for Turkish çünkü 'because'; ${ }^{47}$ here one might probably speak of lexicalised $w h-\dot{z}$, in Polish. The other finding, presented as example (2), again contains a dismissive note, expressed by an imperative in the Turkish original: Bırak şimdi 'Forget about'. It is only in the Polish translation that a wh-construction is used: Kogóż obchodzi 'Whom the heck does it concern'. One might here speak of an 'intensified dismissive', interrogative in the Polish translation, non-interrogative in the Turkish version; the effect of intensity in the Turkish version can be related to the frontedness of the imperative verb, in the sense of Erdal: ${ }^{48}$

\footnotetext{
44 Baydar, Kayıp söz, 11, 51; Baydar, Utracone Stowo, 10, 57.

45 Kemal, Binboğalar Efsanesi, 38; Kemal, Legenda Tysiąca Byków, 37.

46 Göksel, Kerslake, Turkish: A Comprehensive Grammar, 522f.

47 Baydar, Kayıp söz, 36; Baydar, Utracone Stowo, 40.

48 Erdal, "Das Nachfeld im Türkischen und im Deutschen, 53-94.
} 
(2a) Turkish

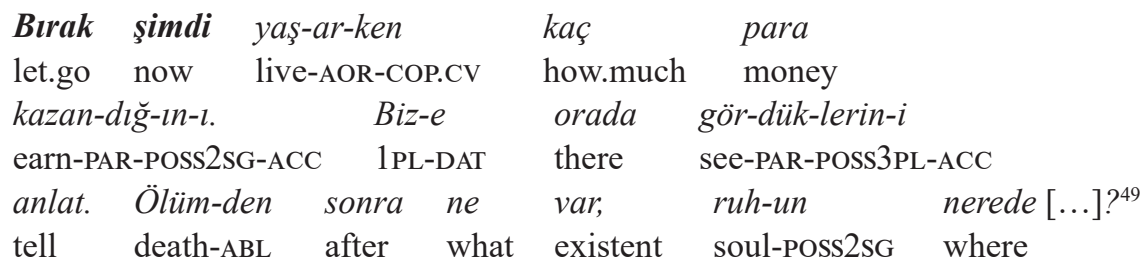

'Forget about how much you earned in your lifetime. Tell us what you see there.

What is there after death, where is your soul $[\ldots]$ ?'

(2b) Polish

\begin{tabular}{|c|c|c|c|c|c|}
\hline \multirow{3}{*}{$\begin{array}{l}\text { Kogó- } \dot{z} \\
\text { who.ACC- } \dot{z} \\
\dot{z} y c i a ? \\
\text { life.GEN }\end{array}$} & \multicolumn{2}{|c|}{$\begin{array}{l}\text { obchodzi, } \\
\text { concern.PRS.3sG }\end{array}$} & \multirow{3}{*}{$\begin{array}{l}\text { ile } \\
\text { how.much } \\
\text { nam, } \\
\text { 1PL.DAT }\end{array}$} & \multicolumn{2}{|c|}{$\begin{array}{l}z a \\
\mathrm{ADP}\end{array}$} \\
\hline & Lepiej & opowiedz & & widzisz. $[\ldots]$ & $C z$ \\
\hline & better & tell.IMP & & see.PRS.2sG & Q \\
\hline & jakieś & zycie & po & śmierci? & \\
\hline $.2 \mathrm{SG}$ & any & life.SG. & after & death.LOC & \\
\hline zebywa & twoja & & dusza $?^{50}$ & & \\
\hline PRS.3SG & $\mathrm{POSS} 2 \mathrm{~s}$ & NOM.F & soul & & \\
\hline
\end{tabular}

'Whom the heck does it concern how much you earned in life? Better tell us what you see there. Is there any life after death? Where is your soul [...]?'

In eleven instances, however, Polish $w h-\dot{z}$ simply goes back to Turkish bare $w h$. The question here is which phenomena might have led translators to assume an intensification of the $w h$-illocution requiring $w h-\dot{z}$ in Polish. Let us look at example (3). In the Turkish version, the $w h$ is not marked by means of any particle, and it syntactically sits in the neutral position of a subject. The position of the entire $w h$-construction within the sentence might be of some interest: the topic, all the remembered aspects of the situation (i.e., the place, the year, the action, the fact that there were some people) is packed into a nominal actor clause ([...] tahliye edilenler 'those evacuated [...]') at the beginning of the sentence, whereas the interrogative part kimlerdi is in the focus. While this might account for a slightly intensifying effect, it might also be considered in the range of what is expectable for a question, thus not particularly intense. I would like to argue in this connection that the impression is rather created at the lexical level here, namely by the description of the mental processes that surround the question: the insistent character of the attempt at remembering (Belleğini zorluyor 'He forces his memory'), the almost successful retrieval of information obtained earlier (dinlemiştim eskiden 'I had heard [...] earlier'), and the despair at the eventual vainness of the attempt, ventilated in a double curse.

49 Pamuk, Benim Adım Kırmızı, 6.

50 Pamuk, Nazywam Się Czerwień, 8. 
(3a) Turkish

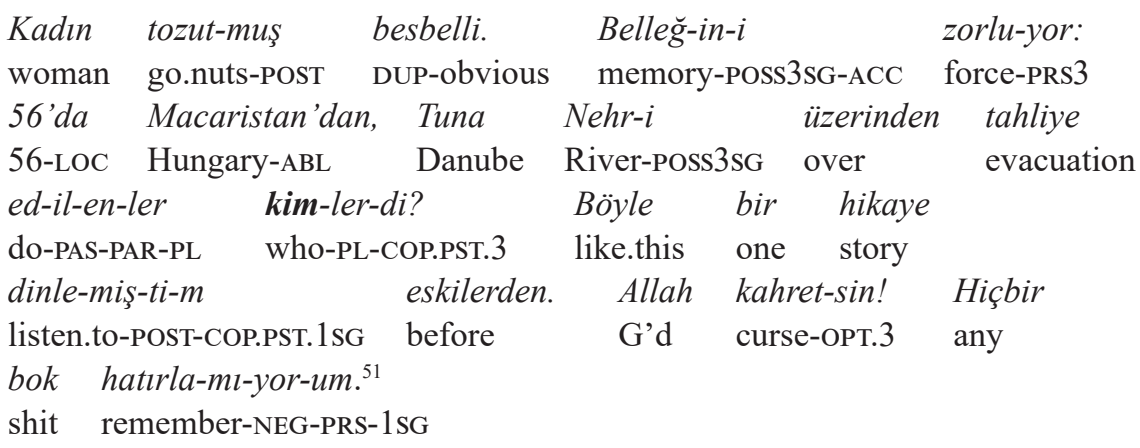

'The woman is clearly nuts. He forces his memory: in 56 in Hungary, who were those who were evacuated over the Danube River? I had heard such a story earlier. Dammit! I can't remember any shit.'

(3b) Polish

$\begin{array}{llllll}\text { To wariatka, } & \text { nie } & \text { ma } & \text { watpliwości. } & \text { Usilnie } \\ \text { DEI madwoman } & \text { NEG } & \text { have.PRS.3SG } & \text { doubt-GEN.PL } & \text { hard } \\ \text { starat się sobie przypomnieć: } & \text { kogó- } \dot{z} \text { to } & \text { na } \\ \text { try.PST.3SG RFL RFL remember.INF } & \text { who- } \dot{z} \text { DEI in }\end{array}$

Węrzech $\quad w$ pięćdziesiatym.szóstym wywożono Dunajem?

Hungary-LOC in fifty-sixth-LOC transport.IPRS Danube-INS

Ktoś mi kiedy-śs o tym opowiadat. Do

who-śs 1SG.DAT when-śs about DEI.LOC tell.PST.3sG to

diabta! $\mathrm{Ni}$ za cholere nie moge sobie

devil.GEN nothing ADP cholera-ACC NEG can.PRS.1SG RFL

przypomnieć. $^{52}$

remember.INF

'That's a madwoman, there's no doubt. He tried hard to remember: whom on earth did they transport over the Danube in Hungary back in fifty-six? Somebody once told me about this. To hell with it! I can't bloody remember anything.'

In (4), an invocative imploration, the situation is one of utmost existential pressure. The character in the scene expresses his needs and wishes by means of imperatives and optatives. To strengthen his cause, he draws attention to a logical pattern: if he had been given a means to exist in the past, then what about the present situation? While this context gives his question the highest urgency, morphosyntactically, there is nothing special. Regarding syntactic movement, the wh-construction is too short to be analysable: ne oldu 'what has happened?'. Its Polish counterpart, by contrast, carries an intensity marker: cóż więc? 'so what the heck?'. In this 
way, context information given in the original is being rendered a morphological form in the translation.

(4a) Turkish

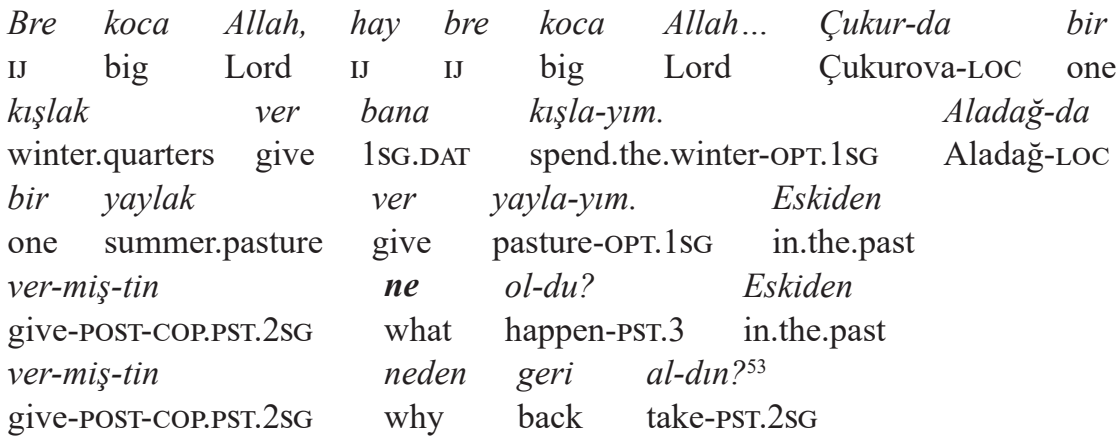

'Hey, Lord, hey, oh big Lord... Give me winter quarters in Çukurova so I can spend the winter. Give me a summer pasture near Aladağ so I can pasture. In the past, you had given, what has happened? In the past, you had given, why did you take it back?'

(4b) Polish

\begin{tabular}{|c|c|c|c|c|c|c|}
\hline Hej & wielk & Boże; & wielki & Allahu... & $d a j$ & $m i$ \\
\hline & $2 \mathrm{sg}$ & Lord & big & Lord & give.IMP & 1SG.DAT \\
\hline & ziemę & kyszłak & $w$ & Czukurowie, & $d a j$ & \\
\hline & winter.ACC & winter.quarter & in & Çukurova.LOC & give.I & \\
\hline & $n a$ & lato & jajłak & koło & Aładah & \\
\hline
\end{tabular}

1SG.DAT for summer.ACC summer.pasture near Aladăg.GEN

Dawniej dawateś, cóż więc? Czemu dajesz earlier give.PST.2SG what- $\dot{z}$ then why give.PRS.2sG

$i \quad$ odbierasz $?^{54}$

and take. PRS.2sG

'Hey, you, big Lord, hey, big Lord... give me for the winter quarters in Çukurova, give me a summer pasture near Aladağ. Earlier, you used to give, so what the heck? Why do you give and take?'

In example (5) below, things look slightly different at the syntactic level. One of the characters in the passage remembers his wife's somewhat sparse reaction to his phone call from a longer journey. While many of the expected emotions remain unexpressed on her side, there is one that does get expressed, namely a tension in connection with the timing of the call: neden sabahın köründe aradığıma 'why I was calling at the crack of dawn'. The $w h$-construction here is embedded, such that part of its illocution is delegated to the higher 
clause ${ }^{55}$ still, the $w h$-element neden 'why' has been preposed, intensifying the urgency of the question. ${ }^{56}$ In the upper clause, the emotion of the scene is lexically characterised in terms of tedirginlik 'tension', taken up in the translation as niepokój 'anxiety' or 'restlessness'. The translation renders the urgency of the question by means of the morphological intensifier $-\dot{z}$ attached to the wh-element: cóż takiego może oznaczać mój telefon o bladym świcie "what of this kind the heck my phone could mean at the crack of dawn'. In addition, the modification of the wh-element by means of the attributive deixis (takiego 'such.gen', 'of this kind:' có $z$ takiego 'lit.: what the heck of this kind') renders it syntactically heavier. This added degree of syntactic weight could be interpreted in terms of an emphatic effect, which might have to be added to that of the suffix $-\dot{z}$. If this analysis is adequate, one might then speak of a double intensity marking here, rendering the likewise marked effect of a wh-element fronted in a subordinate construction in the Turkish original.

(5a) Turkish

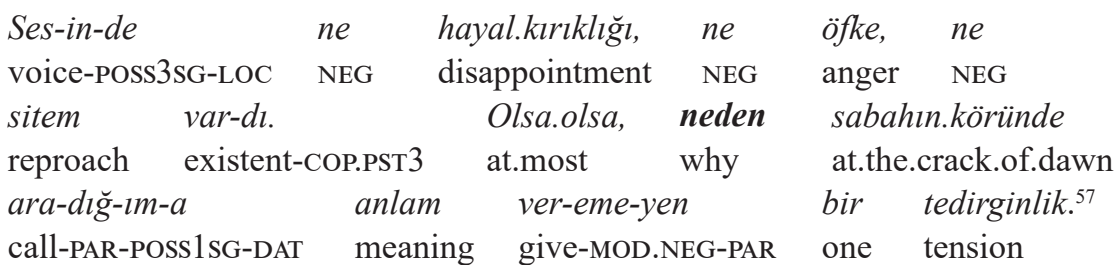

'In her voice there was neither disappointment, nor anger, nor reproach. At most, a tension that could not make sense of why I was calling at the crack of dawn.'

(5b) Polish

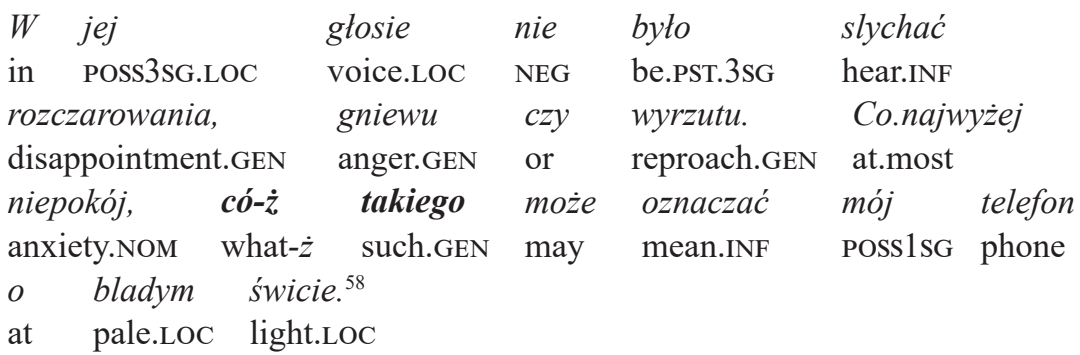

'In her voice there was neither disappointment, nor anger, nor reproach to be heard. At most, an anxiety what the heck [of this kind] my phone could mean at the crack of dawn.'

55 Jochen Rehbein, "Matrix constructions", in Connectivity in Grammar and Discourse (Amsterdam: Benjamins, 2007, 419-447.

56 Erdal, "Das Nachfeld im Türkischen und im Deutschen, 53-94.

57 Baydar, Kayıp söz, 30f-31.

58 Baydar, Utracone Stowo, 32. 


\section{Looking from the $k i$-side}

In what follows, the data will be considered from the opposite perspective. Among the thirteen $k i$-marked $w h$-constructions in the Turkish original that were not translated in terms of $w h-\dot{z}$, two were rendered as negatives; example (6) illustrates this. One might criticise this particular passage of the translation for not being as precise as it could have been. However, the main point from the original still comes across: only by assuming that the character's (a young girl's) speculations (whatever they may be in particular) are correct can one understand her mother's fear of newspapers. The main interesting feature in this passage is the replacement of an intensified wh-question (neden [...] ürksün ki 'why on earth should she be afraid') by a negative construction (nie bałaby się 'she wouldn't be afraid'). Again, in this example, intensity-marked $w h$ seems to be about dismissal of a question: there is no need to ask for reasons other than those already suggested; there can be no other reason.

(6a) Turkish

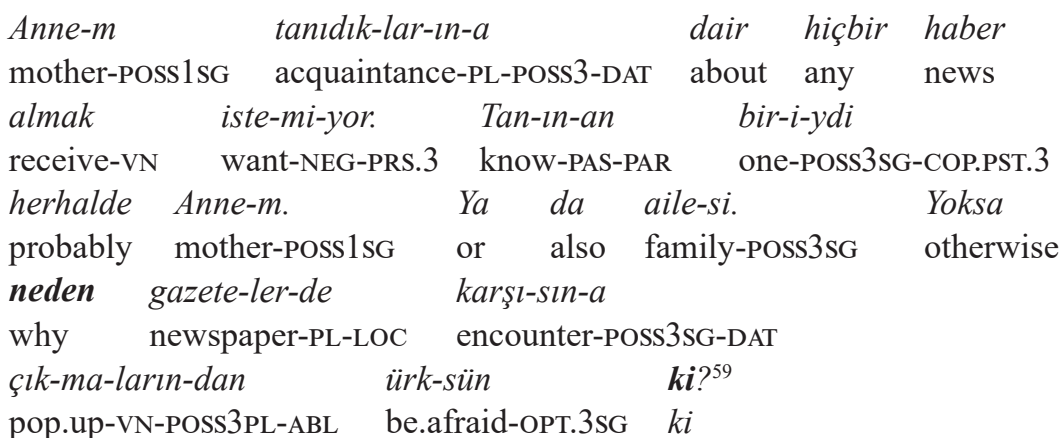

'My mother does not want to receive any news about her acquaintances. She probably was somebody well-known, my mother. Or her family. Otherwise, why on earth should she be afraid of them popping up against her in the papers?'

(6b) Polish

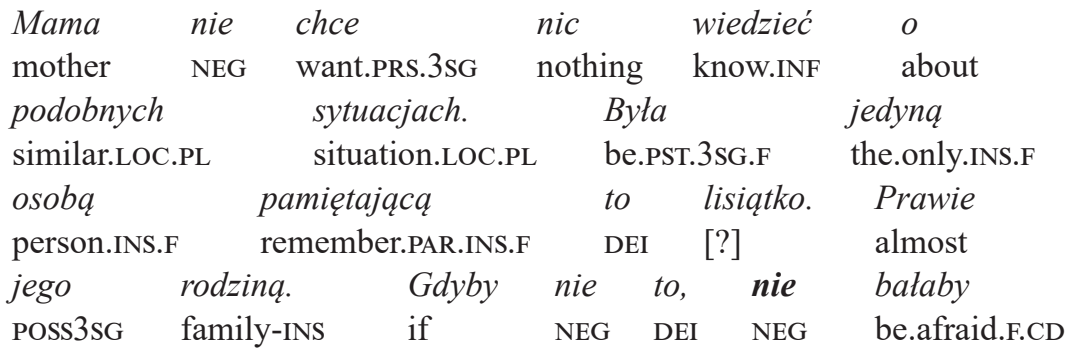

59 Mağden, Biz Kimden Kaçıyorduk Anne?, 15. 
$\begin{array}{lll}\text { się } & \text { czytać } & \text { gazet }^{60} \\ \text { RFL } & \text { read.INF } & \text { newspaper.GEN.PL }\end{array}$

'Mum doesn't want to know anything about similar situations. She was the only person remembering that [?]. Almost her family. If it weren't for that, she wouldn't be afraid to read newspapers.'

Among the eleven $k i$-marked $w h$-interrogatives that were translated into Polish by means of bare $w h$, one can once more observe a range of emotional-illocutionary shades between dismissal and intensification. In (7), a father is trying to talk his little son out of his plans for an unrealistic daytrip. His argument refers to the timing: at such a time, nobody would be out and about, but this fact first has to be unearthed through a question: [...] karga kahvaltısinı etmeden kim uyanir $k i$ ! 'Who on earth would wake up [...] before [even] the crow has had its breakfast!' While the uncontroversial answer seems obvious to himself, it may not be as obvious to his little son, and in this sense, it can still be regarded as a question in search of a real answer. The wh-illocution here may be characterised as intensified and dismissive at the same time; both can be functions of $k i$. It might even be the case that taken together, these two aspects of the illocution can be perceived as neutralising each other; for in the Polish translation, there is just a bare wh: Kto [...] wstaje o takiej barbarzyńskiej porze? 'Who will get up [...] at such an uncivilised hour?'

(7a) Turkish

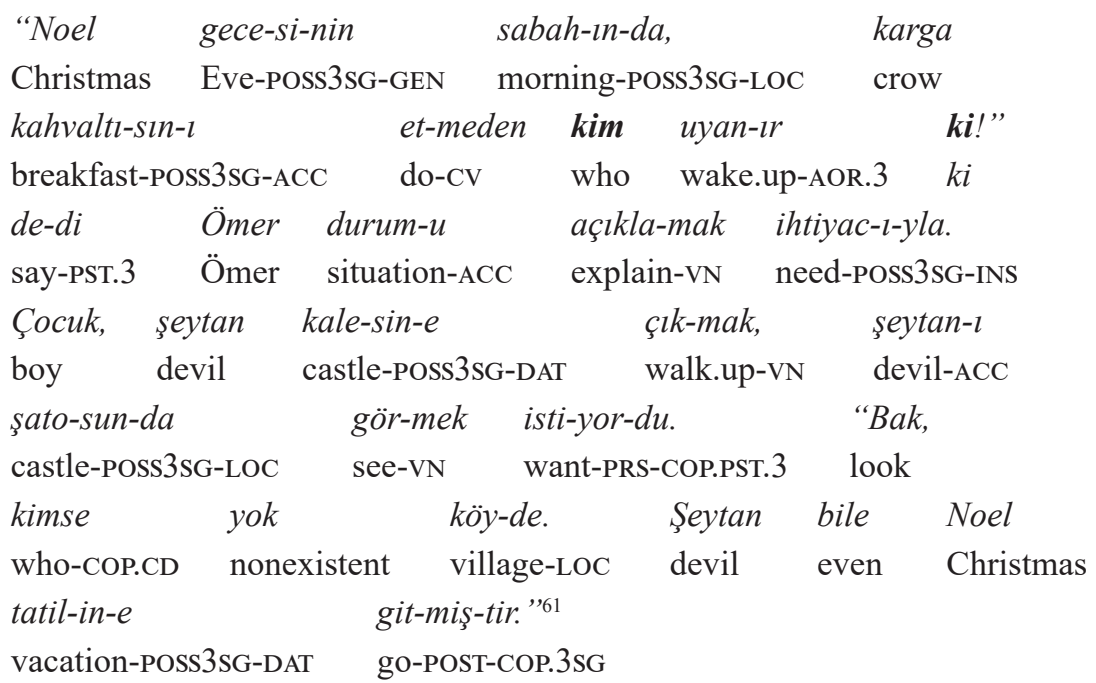

'Who on earth would wake up on the morning of Christmas Eve before [even] the crow has had its breakfast!" said Ömer, needing to explain the situation. The boy wanted to walk up to the devil's castle and see the devil in his palace. "Look, there's nobody in the village. Even the devil has gone on Christmas vacation."”

60 Mağden, Przed Kim Uciekamy, Mamo?, 14.

61 Baydar, Kayıp söz, 30. 
(7b) Polish

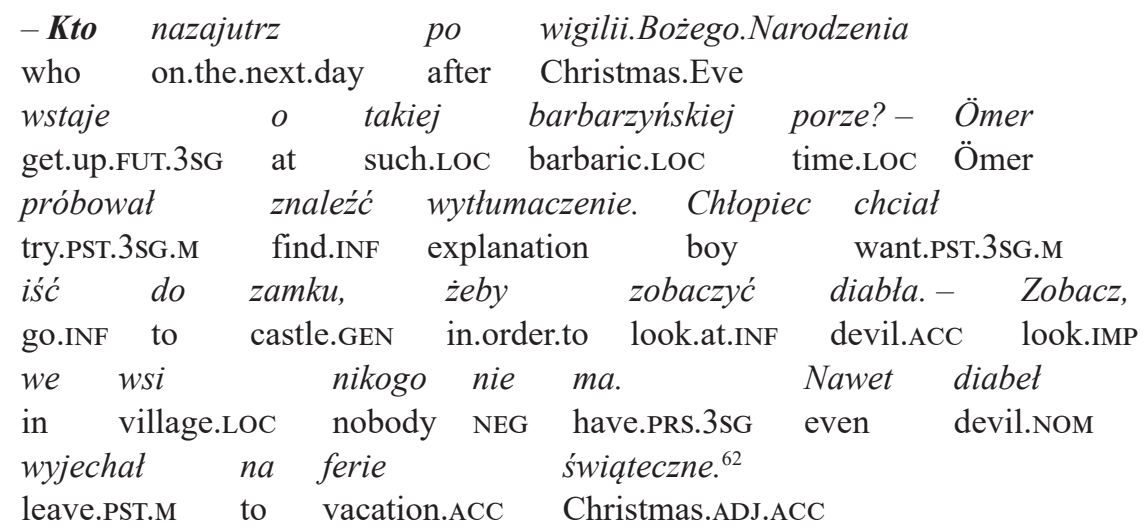

'- Who will get up on the next day after Christmas Eve at such an uncivilised hour? - Ömer was trying to find an explanation. The boy wanted to go to the castle in order to look at the devil. - Look, there's nobody in the village. Even the devil has gone on Christmas vacation.'

The following example (8) has a more clearly intensified tone. A well-established writer has helped a young couple of strangers in distress, and some kind of relationship has developed. The young man is asking the writer for yet another favour but stops short, realising that the other may also have other things to do. The $w h$-question verbalises a newly emerging aspect of the situation, coming to the young speaker's mind while he is talking: Aslinda niye yapasinız ki? 'Actually, why of all things should you want to do it?' In the Polish translation, this emotional shade is recreated by means of bare $w h$, which is however preceded by the particle niby 'as if, seemingly, like', possibly expressing at that level the tentative character of the newly emerging idea. The function of $k i$ in this example might then best be described in terms of doubt, a sudden change of mind, or disbelief, all mentioned by Göksel and Kerslake, ${ }^{63}$ albeit not in connection with $k i$ in particular, or even in terms of anxiety. ${ }^{64}$ This question is not dismissed with any intensity comparable to the preceding examples; the answer seems less obviously clear.

62 Baydar, Utracone Stowo, 32.

63 Göksel, Kerslake, Turkish: A Comprehensive Grammar, 307-309.

64 Lewis, Turkish Grammar, 214. 
(8a) Turkish

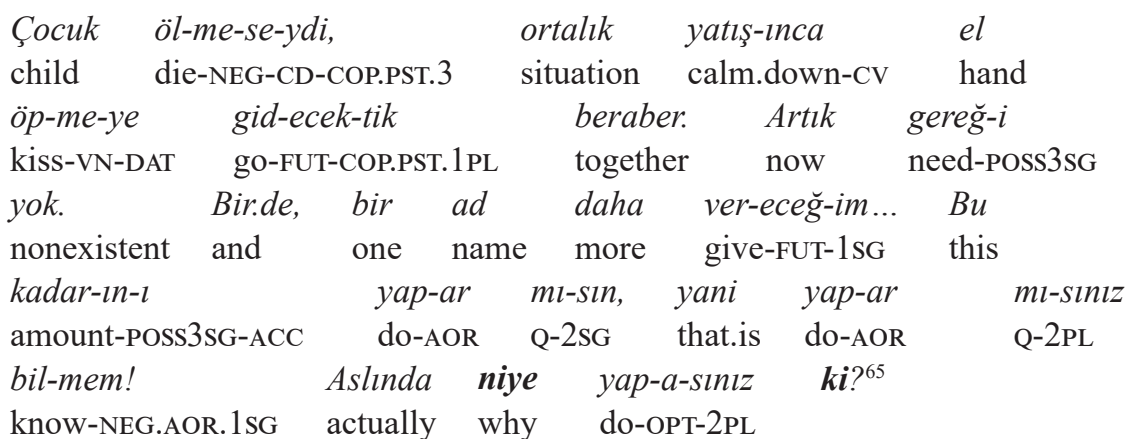

'If the child hadn't died, as soon as the situation would have calmed down, we'd have gone [there] together to kiss hands. Now there's no need to any more. And, I'll give you yet another name... Would you [familiar] do this much, that is, would you [formal] do it, I don't know! Actually, why on earth would you want to do it?'

(8b) Polish

Gdyby nie umarto, pojechalibyśmy, gdy sprawa if NEG die.Pst.3sG go.CD.1PL when matter ucichnie, ucałować jego ręce $i$ prosić calm.down.PRS.3sG kiss.INF POSs3sG hand.ACC.PL and ask.INF o blogostawieństwo. Ale teraz nie ma po co. ADP blessing.ACC but now NEG have.PRS.3SG for what I jeszcze podam panu pewne nazwisko... Czy and still give.FUT.1SG Sir.DAT certain.ACC name.ACC Q zrobi pan to dla mnie? To znaczy, nie do.FUT.3sG Sir.NOM DEI for 1SG.GEN DEI mean.PRS.3sG DEI wiem, czy pan zechce. Bo niby czemu know.PRS.1sG JNC.Q Sir.NOM want.PRS.3SG because PTC why miatby pan to robić? ${ }^{66}$

have.CD.3SG Sir.NOM DEI do.INF

'If it hadn't died, we'd go, when the matter calms down, to kiss his hands and ask for his blessing. But now there's no need to. And I'll give you yet another name... Will you do this for me? That means, I don't know whether you'll do it. For like why would you do this?'

In (9a), a young girl is trying to understand aspects of her mother's past, which has been largely withheld from her. Those bits of knowledge that do get imparted on her raise a variety of questions. The girl's mother started smoking very young and describes her own addiction in 
terms of a lack of other remedies and a need for comfort and distraction. These few cues seem to virtually trigger an entire series of quite specific knowledge deficits rising to the surface of the young girl's mind. Only the first of them is marked by means of ki: Neden çaresiz kalmış ki Annem? 'Why on earth did she end up remediless, my mother?'; however, the subsequent two questions, being closely connected and of existential relevance, seem to fall under its scope, too (Neler yaşamış? 'What did she live through?' Annesi kim Annemin; benim anneannem? 'Who is her mother, my mother's, my grandmother?'). These questions, to which the answer is not known, are far from being dismissed in this situation; they are being intensely asked. They do, however, lack an addressee, for the girl lives in isolation with her mother and has learned not to unsettle her with certain types of questions. In this sense, her interrogatives may be described as highly intense while at the same time parts of the illocution are blocked: without a communicatively available addressee, these questions cannot be resolved.

In the Polish translation (9b), the scene is rendered by means of bare wh-questions, making, at first sight, for a somewhat quieter atmosphere than in the original. However, here again, we find the same element as in (5b): takiego 'such.gen' in Co takiego przeżytaś? 'What [of this kind] did you go through?', which, by the syntactic weight that it adds, may create an intensifying effect. This marker does not occur in the first question, which is where the ki occurs in the original, but in the middle one of the three questions - which one might take as another indication of the inter-sentential scope of the $w h$-illocution in this passage. Another detail in this connection is the direction of address of this question: in the Polish translation, the girl addresses the question to her mother, using the second person. This is not the case in the Turkish original, which is more of a soliloquy, using the third person; however, from the context, it is clear that the interactional reality of the questions is an imagined one in both versions.

(9a) Turkish

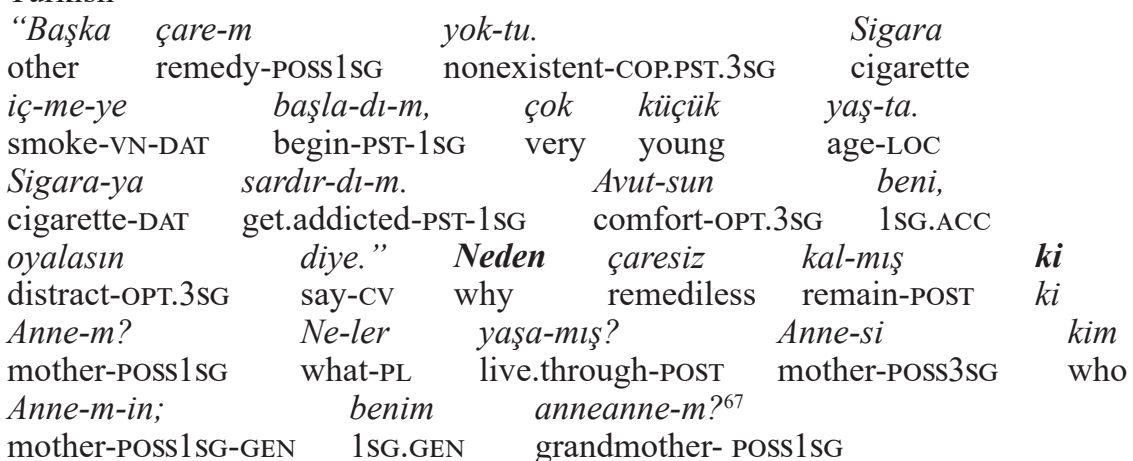

" "I had no other remedy. I started smoking cigarettes, at a very young age. I got addicted to the cigarettes. For them to comfort me, to distract me." Why on earth did she end up remediless, my mother? What did she live through? Who is her mother, my mother's, my grandmother?' 
(9b) Polish

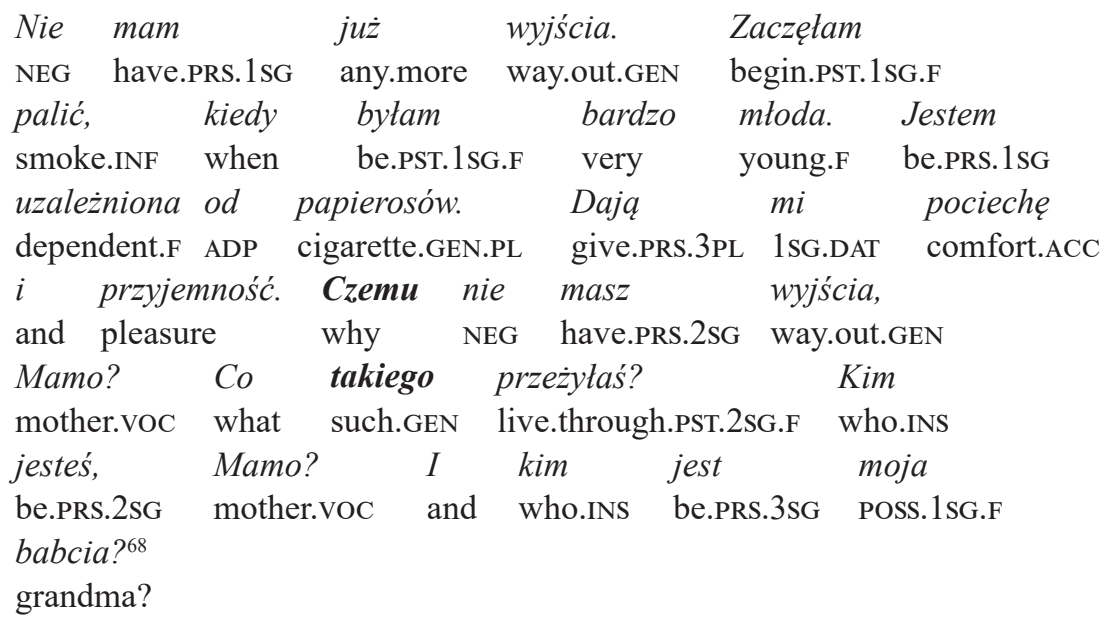

'I have no way out any more. I started smoking when I was very young. I am dependent on cigarettes. They give me comfort and pleasure. Why do you not have a way out, mother? What [of this kind] did you go through? Who are you, mother? And who is my grandma?'

(10a), again, is a clearer case of dismissive $w h$. The talk is about a series of miniature drawings that someone discovered in a calligrapher's workshop, some time back in history. The issue is a sensitive one, calling for discreet and prudent handling. The artworks will have to be effectively disposed of; Başka ne yapabiliriz ki? 'What else can we do?' The question here once more is dismissive; it is clear that there aren't by any stretch of the imagination any other options available. In addition to the dismissal, one can, here also, note a shade of resignation as a further aspect of the wh-illocution. In the Polish translation (10b), there is no particular morphological marking, so it may have to be left open whether in the translational process, this shade of the illocution was considered apparent enough from the context or whether any morphological marking might have been considered as too strong in a context in which an illocutionary softening was perceived as the main effect to be recreated.

68 Mağden, Przed Kim Uciekamy, Mamo?, 12. 
(10a) Turkish

"Sonra siz ne yap-acak-sınız?" "Söy-ler-im Enişte

after.that 2PL what do-FUT-2PL tell-AOR-1SG brother.in.law

Efendi'ye, resim-ler-i yak-ar. Başka ne

Efendi-DAT drawing-PL-ACC burn-AOR.3SG other what

yap-abil-ir-iz $\quad \boldsymbol{k i} ?^{69}$

do-MOD-AOR-1PL $\quad k i$

"'What will you do after that?" "I will tell my brother-in-law, he will burn the drawings. What else can we do?"

(10b) Polish

$\begin{array}{llllll}-A & \text { ty } & \text { co } & \text { potem } & \text { zrobisz? }- & \text { Powiem } \\ \text { and } & \text { 2sG.NOM } & \text { what } & \text { after.that } & \text { do.FUT.2SG } & \text { tell.FUT.1sG }\end{array}$

Wujowi, by spalit miniatury. Co innego

uncle.DAT JNC burn.PAR miniature.PL.ACC what other.GEN

możemy zrobić? ${ }^{70}$

can.PRS.1PL do.INF

'-And what will you do after that? - I will tell the uncle to burn the miniatures.

What else can we do?"

\section{Conclusions}

This has been an attempt at parallelising means of modifying the illocutionary qualities of wh on the basis of original passages from contemporary Turkish novels and their translations into Polish. This project started out on the assumption of a striking parallelism between Turkish $w h$... ki and Polish $w h$-z; however, after some quantifying work, this assumption had to be put in place. In the majority of the findings, it was discovered that Turkish $w h \ldots k i$ is translated into bare $w h$ in Polish while Polish $w h-\dot{z}$ appears in translations of Turkish bare $w h$. This state of affairs raised questions of explanation and further detail.

The data basis for this little project has been small; to base it on an expanded set of data would have required state-of-the-art corpus-linguistic infrastructure, yet to be built in a long-term co-operative setting. It may thus be too early to attempt much in the way of a generalisation; however, for the time being, the following can be retained: (1) While Turkish wh... ki may occasionally be left unexpressed in the Polish translations, there are several means other than $w h-\dot{z}$ that help to express emotional shades on a range between intensification and dismissal or some related emotions such as a tentative change of idea. Polish wh modifiers that might deserve further attention in this connection are niby 'as if, seemingly, like' in example (8) and takiego 'such.gen' (9). Occasionally, the perceived repudiative character of a wh-construction may alternatively take the translation into neighbouring functional

69 Pamuk, Benim Adım Kırmızı, 14.

70 Pamuk, Nazywam Się Czerwień, 36. 
areas such as negation (6). In other instances, the $k i$ element may remain unrepresented in the translation $(7,10)$.

(2) On the other hand, Polish $w h-\dot{z}$ rarely emerges entirely out of the blue in the translations even when there is no $k i$ in the original. What one rather finds are entire wh-phrases syntactically moved into the focus as in (3), lexical means of emotional description (3), religiously connotated invocation (4), and wh-fronting in (the somewhat marked surroundings of) a subordinate clause (5). Occasionally, a non-wh-construction may end up translated as $w h-\dot{z}$, e.g., in the case of a fronted imperative (2).

(3) The overlap area, i.e., the small collection of four passages which feature both wh... $k i$ in the Turkish original and $w h-\dot{z}$ in the Polish translation, reveals that in these instances, one can safely speak of a dismissive character of the wh-questions. However, interestingly, even if not at the level of those aspects of the wh-illocution that would prompt an addressee to verbalise an answer, a certain intensity of the questioning can still be said to be given.

(4) As emerges, neither $w h$... ki nor $w h$-ż can simply be subsumed under the term 'intensified $w h$ '. As already suspected from the literature, the range of emotional-illocutionary dynamics is quite considerable. One may speak of 'intensity' as some kind of core meaning, however, in addition to being 'intense', a wh-question may or may not be addressed to a hearer, it may or may not imply a serious search for an answer, and the answer may be anything from alltoo-obvious to unobtainable. What I have termed the 'dismissive' character of several of the wh-uses can be anything from a desperate abandonment of a search accompanied by curses to more or less mild resignation. Occasionally, $k i$ can mark a newly emerging question, i.e., a question on its way in rather than out, as in (8a).

Table 4 is a qualitative differentiation based on Table 3 in Section 3, considering just those examples that have been presented for a closer look; it additionally lists any further morphosyntactic phenomena that might functionally correspond to $w h-\dot{z}$ or $w h \ldots k i$.

Table 4: Phenomena possibly corresponding to $w h-\dot{z}$ and $w h \ldots k i$ in individual examples

\begin{tabular}{|c|c|c|c|}
\hline Polish & $w h . . . k i$ & bare $w h$ (plus) & no wh \\
\hline \multirow{3}{*}{$w h-\dot{z}$} & \multirow{3}{*}{ (1) $w h \ldots k i=w h-\dot{z}$} & (3) $w h$-phrase in focus position, lexical description & \multirow{3}{*}{$\begin{array}{l}\text { (2) fronted } \\
\text { imperative }\end{array}$} \\
\hline & & (4) invocation & \\
\hline & & (5) fronted $w h$ in subordinate clause, Polish: $w h$-ż takiego & \\
\hline \multirow{4}{*}{ bare $w h$} & (7) $w h$ & & \\
\hline & (10) $w h$ & & \\
\hline & (8) niby wh & & \\
\hline & (9) wh takiego & & \\
\hline no $w h$ & (6) negation & & \\
\hline
\end{tabular}




\section{Abbreviations}

\begin{tabular}{|l|c|c|c|c|c|}
\hline 1 & first person & DUP & reduplication & NEG & negation \\
\hline 2 & second person & DEI & deixis & NOM & nominative \\
\hline 3 & third person & EMPH & emphasis, intensity & PAR & participle \\
\hline ABL & ablative & F & feminine & PAS & passive \\
\hline ACC & accusative & GEN & genitive & PL & plural \\
\hline ADJ & adjective & IJ & interjection & POST & postterminal \\
\hline ADP & adposition & IMP & imperative & PRS & present tense \\
\hline AOR & aorist & INDEF & indefinite & PST & past tense \\
\hline CD & conditional & INF & infinitive & POSS & possessive \\
\hline COP & copula & INS & instrumental & PTC & particle \\
\hline COP & copula & IPRS & impersonal & Q & interrogative \\
\hline CV & converb & JNC & junctor & QTF & quantifier \\
\hline DAT & dative & LOC & locative & RFL & reflexive \\
\hline DER & derivation & M & masculine & VN & verbal noun \\
\hline DET & determiner & MOD & modality & VOC & vocative \\
\hline
\end{tabular}

Peer-review: Externally peer-reviewed.

Conflict of Interest: The author has no conflict of interest to declare.

Grant Support: The author declared that this study has received no financial support.

Acknowledgements: I wish to thank my Turkish grammar class students at Uniwersytet im. Adama Mickiewicza w Poznaniu for inspiring me to put together a parallel corpus for data-driven analysis and for beginning to put it to their own creative use.

\section{Data}

Baydar, Oya. Kayıp söz [The Lost Word]. İstanbul: Can Yayınları, 2011 [2007].

Baydar, Oya. Utracone Stowo [The Lost Word] [translated from the Turkish by Anna Akbike Sulimowicz]. Katowice: Wydawnictwo Sonia Draga, 2013.

Kemal, Yaşar. Binboğalar Efsanesi [The Legend of the Thousand Bulls]. İstanbul: Yapı Kredi, 2007 [1971].

Kemal, Yaşar. Legenda Tysiąca Byków [The Legend of the Thousand Bulls] [translated from the Turkish by Wojciech Hensel]. Warszawa: Państwowy Instytut Wydawniczy, 1983.

Mağden, Perihan. Biz Kimden Kaçıyorduk Anne? [Whom Were We Running from?] İstanbul: Can Yayınları, 2007. Mağden, Perihan. Przed Kim Uciekamy, Mamo? [Whom Were We Running from?] [translated from the Turkish by Marcin Błaszak]. Warszawa: Świat Książki, 2011.

Pamuk, Orhan. Benim Adım Kırmızı [My Name Is Red]. İstanbul: İletişim Yayınları, 1998 [1990].

Pamuk, Orhan. Nazywam Się Czerwień [My Name Is Red] [translated from the Turkish by Danuta Chmielowska].

Kraków: Wydawnictwo Literackie, 2007. 


\section{References}

Akar, Didar. "Wh-questions in Turkish”, editor Bengisu Rona, Current Issues in Turkish Linguistics, 67-74. Volume II. Ankara: Hitit Yayınları, 2000.

Banguoğlu, Tahsin. Türkçenin Grameri. İstanbul: Edebiyat Fakültesi Basımevi, 1974.

Barbaresi, Lavinia Merlini \& Dressler, Wolfgang U. "Pragmatic explanations in morphology", editors Vito Pirrelli, Ingo Plag \& Wolfgang U. Dressler, Word Knowledge and Word Usage: A Cross-Disciplinary Guide to the Mental Lexicon (Berlin: De Gruyter Mouton, 2020), 405-454.

Bielec, Dana. Polish: An Essential Grammar. London: Routledge, 1998.

Charitonidis, Chariton. "The Morphology-Pragmatics Interface in Modern Greek Compounding”, Poznań Studies in Contemporary Linguistics 51/1 (2015): 27-73.

Chomsky, Noam. Knowledge of Language: Its Nature, Origin and Use. N.Y.: Praeger, 1986.

Cinque, Guglielmo \& Rizzi, Luigi. “The Cartography of Syntactic Structures”, editors Bernd Heine \& Heiko Narroq, The Oxford Handbook of Linguistic Analysis, 51-66. Oxford: OUP (Oxford Handbooks in Linguistics), 2010.

Ehlich, Konrad \& Rehbein, Jochen. "Sprachliche Handlungsmuster [Linguistic patterns of action]", editor Hans-Georg Soeffner, Interpretative Verfahren in den Sozial- und Textwissenschaften, 243-274. Stuttgart: Metzler, 1979.

Erdal, Marcel. "Das Nachfeld im Türkischen und im Deutschen [The postfield in Turkish and in German]", editors Lars Johanson \& Jochen Rehbein, Türkisch und Deutsch im Vergleich, 53-94. Wiesbaden: Harrassowitz (Turcologica 39), 1999.

Erguvanlı Taylan, Eser. “A case of syntactic change: ki constructions in Turkish”, Bogaziçi Üniversitesi Dergisi (Istanbul) 8-9 (1981): 111-139.

Göksel, Aslı \& Celia Kerslake. Turkish: A Comprehensive Grammar. London: Routledge (Routledge Comprehensive Grammars), 2005.

Göksel, Aslı \& Özsoy, A. Sumru. "Is there a focus position in Turkish?”, editors Aslı Göksel \& Celia Kerslake, Studies on Turkish and Turkic Languages, 219-228. Wiesbaden: Harrassowitz (Turcologica 46), 2000.

Göksel, Aslı \& Özsoy, A. Sumru. “dA: as a focus/topic associated clitic in Turkish”, Lingua 113 (2003): $1143-1167$.

Herkenrath, Annette. Wh-Konstruktionen im Türkischen [Wh-constructions in Turkish]. Wiesbaden: Harrassowitz (Turcologica 87), 2011.

İşsever, Selçuk. "A syntactic account of wh-in-situ in Turkish", editors Sıla Ay, Özgür Aydın, İclal Ergenç, Seda Gökmen, Selçuk İşsever \& Dilek Peçenek, Essays on Turkish Linguistic: Proceedings of the 14th International Conference on Turkish Linguistics, August 6-8, 2008, 103-112. Wiesbaden: Harrassowitz (Turcologica 79), 2009.

Kiefer, Ferenc. "Morphology and Pragmatics", editors Andrew Spencer \& Arnold M. Zwicky, Handbook of Morphology, 272-280. Oxford: Blackwell, 1998.

Korkmaz, Zeynep. Türkiye Türkçesi grameri: Şekil bilgisi. 3. bask1. Ankara: Türk Dil Kurumu, 2009 [2003]. Kornfilt, Jaklin. "On Some Infinitival Wh-Constructions in Turkish”, Dilbilim Araştırmaları 1996: 192-215. Kornfilt, Jaklin. Turkish. London: Routledge, 1997. 
Kornfilt, Jaklin. "On rightward movement in Turkish”, editors Lars Johanson in cooperation with Éva Á. Csató, Vanessa Locke, Astrid Menz \& Dorothea Winterling, The Mainz Meeting: Proceedings of the Seventh International Conference on Turkish Linguistics, August 3-6, 1994, 107-123. Wiesbaden: Harrassowitz (Turcologica 32), 1998.

Lewis, Geoffrey L. Turkish Grammar. Oxford: Oxford University Press, 1997.

Lusekelo, Amani. "Morphology-Pragmatics Interface: The Case of the Tanzanian Commercials in Swahili Newspapers”, Afrikanistik online 2010: 1-22. Retrieved 30 July 2021. http://www.afrikanistik-online. de/archiv/2010/2711.

Orda, Napoléon. Grammaire analytique et pratique de la langue polonaise à l'usage des français [Analytical and practical grammar of the Polish language for the use of French]. Paris: Martinet, 1856. Last access 28 July 2021. https://archive.org/details/grammaireanalyt01ordagoog/page/n94/ mode/2up.

Oturakç1, Nigâr. "Question words as indefinite pronouns in Turkish", editors Éva Kincses-Nagy \& Mónika Biacsi, The Szeged Conference: Proceedings of the 15th International Conference on Turkish Linguistics held on August 20-22, 2010 in Szeged, 381-388. Szeged: University of Szeged, Department of Altaic Studies (Studia uralo-altaica 49), 2012.

Özsoy, A. Sumru. "A'-dependencies in Turkish”, editor Bengisu Rona, Current Issues in Turkish Linguistics, 140-158. Ankara: Hitit Yayınları, 1996.

Özsoy, A. Sumru. “Turkish as a (non)-wh-movement language”, editors Éva Á. Csató, Grundvald Ims, Joakim Parslow, Finn Thiesen \& Emel Türker, Turcological Letters to Bernt Brendemoen, 221-232. Oslo: Novus Press (The Institute for Comparative Research in Human Culture/ Instituttet for sammenlignende kulturforskning), 2009.

Redder, Angelika. "Sprachwissen als handlungspraktisches Bewusstsein: Eine funktional-pragmatische Diskussion [Linguistic knowledge as action-practical awareness: A functional-pragmatic discussion]", Didaktik Deutsch 5 (1998): 60-76.

Rehbein, Jochen. "Remarks on the empirical analysis of action and speech", Journal of Pragmatics 8 (1984): 49-63.

Rehbein, Jochen. "Zum Modus von Äußerungen [On the mood of utterances]", editors Angelika Redder \& Jochen Rehbein, Grammatik und mentale Prozesse, 91-142. Tübingen: Stauffenburg, 1999.

Rehbein, Jochen. "Matrix constructions", editors Jochen Rehbein, Christiane Hohenstein \& Lukas Pietsch, Connectivity in Grammar and Discourse, 419-447. Amsterdam: Benjamins (Hamburg Studies on Multilingualism 5), 2007.

Rizzi, Luigi. "The Fine Structure of the Left Periphery”, editor Liliane Haegeman, Elements of Grammar, 281-337. Dordrecht: Kluwer, 1997.

Rykaczewski, Erazm. Grammaire de la langue polonaise: Contenant des règles appuyées sur les examples tirés des meilleurs auteurs polonais destinée principalement à l'usage des écoles polonaises à Paris [Grammar of the Polish language: Containing rules based on the examples drawn from the best Polish authors, intended primarily for the use of Polish schools in Paris]. Berlin et Posen: Librairie B. Behr, 1861. Last access 28 July 2021. https://archive.org/details/grammaire delala00rykagoog.

Sadowska, Iwona. Polish: A Comprehensive Grammar. London: Routledge, 2011. 
Sciborski, M. Abrégé De La grammaire polonaise: Sélon les principes \& le raisonnement de la Grammair nationale suivi des Dialogues \& d'un petit Vocabulaire Alphabétique [Abridged Polish Grammar: According to the principles and the reasoning of the National Grammar, followed by dialogues and a small alphabetical vocabulary]. Lucko: Imprimerie privilégiée des Dominicains, 1798. Last access 29 July 2021. https://play. google.com/books/reader?id=bxJAAAAcAAJ\&pg=GBS.PP6\&hl=en_GB.

Swan, Oscar E. A grammar of contemporary Polish. Bloomington: Slavica, 2002.

Vater, Johann-Sévérin. Grammaire abrégée de la langue polonaise consistant en tableaux, règles et examples [Abridged grammar of the Polish language, consisting of tables, rules and examples]. Halle: Gebauer/ Strasbourg: Levrault, 1807. Last access 28 July 2021. https://archive.org/details/ grammaireabrged00vategoog.

Velupillai, Viveka. An Introduction to Linguistic Typology. Amsterdam: Benjamins, 2012.

Zwicky, Arnold \& Geoffrey Pullum, "Plain morphology and expressive morphology", Proceedings of the Thirteenth Annual Meeting of the Berkeley Linguistics Society 1987, 330-340. Retrieved July 30, 2021. DOI: $10.3765 /$ bls.v13i0.1817. 